resection of the infected fundus of the uteris, leaving suffieient healthy uterine body to conserve the menstrual function and one or both ovaries to continue ovulation. The opcration should be clone without interfering with the ovarian cireulation, hemostasis being secured by the ligntion of the individual branches supplying the tube and fundus. With the bleeding eontrolled, a wedge-sbapel excision is made of the upper part of the hody and funclus of the uterus. The anterior incision hegins just posterior to the insertion of the round ligament and runs across the front of the uterus to a corresponding point on the opposite sidc. The posterior incision begins between tlic tubal insertion and the ovarian ligument on onc side and cxtcnds across the posterior surface to the same point on the opposite side. The incision is made in sueh a onanner thit the cntire funclal mucosn witl the pars interstitialis and surrouncling tissues of both sirles are cxeised. Hy menns of this operation, sufficient endometrium is ullowerl to remain to perpetuate menstruation.

\title{
DISEASES OF THE LARYNX AND CONTIGUOUS STRUCTURES
}

ONDER THE CUAROF OF

J. SOIJS-COIIEN, M.D., milHADELPIIA.

Cyst of the Larynx.-( Masmitulis (Laryngosepp, August, 1917) reports $a$ cuse in a well-aleveloped elild who hud bind a peculiar ery almost froul birth, shortly followed ly inspiratory striclor which had become unarkedly worse during six inontlus. There was no listory of dyspnen or of eyanosis. The interior of the larynx could not be inspected witl the uid of the laryngoscopic mirror, but under suspension a large tumor nuss was seen to oecupy the cntire right side of the larynx, rendering a view of the interior impossible. An hypertrophied fold of mucous nembrane at the summit of the left aryepiglottic fold flapped bnck and forth in the air strenm, and accounted for the stertor. It was resected and the stertor eeascd. A long knife inserted into the tumor with a view of determining its consistence gave exit to 1 or 2 drams of a brownish viscid, almost gelatinous liquid, and the tumor collapsed. Careful examination failing to reveal its walls or eren the pound of the stab. It was thonght that the tumor had been situated on the right arycpiglottie fold. An cxeellent and unobstructed view of the entirc larynx and several rings of the trachea was at once possible. There had not been any recurrenee of trouble up to the time of the report.

Excision under Suspension Laryngoscopy of a Carcinoms of the Larynx: No Recurrence in Three Years. - Marer (Laryngoscope, Feloruary, 1917) reports this cuse in which under suspension laryngoscop: be exeised with long-landled, curved right and lift scalpels a curcinomntous epiglottis whieh he exlibited at the New York Academy of Medieiuc. Save for a rather alarming hemorrhage on the second 
day af ter the operation, an uninterrupted recovery ensued. The patient, a man, aged sixty-four years, had not experienced any discomfort whatever from the lass of his epiglottis, deglutition and vocalization being perfect.

Diphtheritic Membranes in the Lung Diagnosed and Removed under Bronchoscopy.-SkulleRN (Laryngoscopy, February, 1917) reports the case of a boy, aged seven yeurs, supposed to have inspirated a bead which accounted for existing cough and at tacks of suffocs tion. Physical exploration of the chest and fluoroscopic examination were practically negative. Under bronchoscopic inspection there was detected, a little above and at the lower lobe bifurcation of the right lung, a membrane which bled on being loosened with a dull hook. It was not deemed prudent to continue manipulation at that moment. Two hours later dyspnen became so urgent as to require immediate tracheotomy. Three days later the membrane was loosened under bronchoscopy and on account of friability was found removable only piecemeal. Some pieces of membrane were coughed out through the cannula during the niglit. The tube was removed on the seventh day, the child being entirely woll. Nine months previous to this clinical history the paticnt had gone through a severe attack of diphtheria followed for some two months by a cough which hind cleared up entirely.

Gunshot Wounds of the Larynx.-Coulet (Reruc de Laryngol., $d$ 'otol. $c$ t de rhinol., July 15, 1917) has found but onc gunshot wound of the larynx among 1200 wounded soldiers under his carc. He reports a casc of gunshot wound of the larynx, followed hy abscess and recurrent paralysis. A bullet from a great distance had passed tlirough the neck without injuring the great vessels, but had injured the arytcnoid region and induced local inflammatory action; and it had injured the recurrent nerve in passing. A good recovery cnsued, but the paralysis of the left recurrent rcmained permanent.

Chancre of the Pharyngesl Tonsil.-HADEN (Jaryngoscopc, August, 1917) reports the case of a married woman, aged twenty-five ycars with headache unaccountable for by her eyes or her general condition. Though there had not hecn any history of trouble in nosc or throat, posterior rhinoscopy, a swollen, bright red pharyngeal tousil witl upparent ulccration of its surface. Three days after an application of urgyrol, though the pain hecame so severe as to require the administration of morphin, the patient expectorated a section of the plaryngeal tonsil which on microscopic inspection was found to contain nunicrous living Spirochetre pallida. At this time a typical sccondary rash appeared upon the body. Salvarsan was administered the next day, and the headrche subsided.

Septic Arthritis following Submucous Resection of the Nasal Septum. -Imperatori (Laryngoscopc, March, 1917) rcports a case of septic arthritis of the knee-joint following resection of the nasal scptum. Fluctuation was evident on the ninth day after the operation. The joint was opened and considerable pus was found with manifestations of extensive destruction of the articular cartilages. 